\title{
Logistics outsourcing partnerships: conceptual model
}

\author{
Chaabouni Fatma ${ }^{1,2, *}$, Dhiaf Mohamed Mahjoub ${ }^{1,2}$ \\ ${ }^{1}$ Management sciences, Tunisia, Sfax \\ ${ }^{2}$ Faculty of economic and management of Sfax, contractual teacher, Tunisia, Sfax \\ Email address: \\ f.chaabouni2@voila.fr (C.Fatma),mohamedmahjoub.dhiaf@fsegs.rnu.tn (D. Mohamed Mahjoub)
}

\section{To cite this article:}

Chaabouni Fatma, Dhiaf Mohamed Mahjoub. Logistics Outsourcing Relationships: Conceptual Model. International Journal of Economics Finance and Management Sciences. Vol. 1, No. 2, 2013, pp. 81-88. doi: 10.11648/j.ijefm.20130102.13

\begin{abstract}
The worldwide usage and importance of logistics outsourcing has grown dramatically over the last decades and will continue to do so. A model of logistics outsourcing relationship is developed and hypotheses are presented regarding the antecedents and consequences of trust. The objective of this research is to describe the relationships between logistics service providers and their customers. It aims at increasing interaction between customers and logistics service providers. Our analysis is based on an extensive survey of the literature on logistics outsourcing relationship.
\end{abstract}

Keywords: Logistics; Outsourcing; Relationship; Model; Trust

\section{Introduction}

Logistics outsourcing and third-party logistics originated in the 1980s as important means of improving supply chain effectiveness [1]. Third-party logistics (TPL) was initially defined as: "the use of external companies to perform logistics functions that have traditionally been performed within an organization. The functions performed by the third party can encompass the entire logistics process or selected activities within this process" [2]. While some companies have made the decision to maintain control of logistics activities, numerous others worldwide have decided to outsource these activities. While research from relationship marketing supplies a number of very relevant insights $[3,4]$, the adaptation by logistics research has been rather scarce $[5,6,7]$. The intention of this study is to contribute to the logistics outsourcing discussion by analyzing the relationships between logistics service providers and their customers. Its starting point is the relationship between the customer and its LSP. For the customer, a main problem is to identify the factors that influence the relationship. This is a complex task: a multitude of different variables and theoretical approaches exist to choose from. Our research framework and our empirical study will be outlined in our doctoral thesis.

\section{Literature Review}

\subsection{Definition of Terms}

\subsubsection{Logistics Outsourcing}

Reference [8] stated that logistics outsourcing is "the use of a third-party provider for all or part of an organization's logistics operations" and added that its utilization by the firms is increasing. Reference [9] defined outsourcing in the context of logistics as: "the practice of charging external service providers with the task of performing in-house activities". The term "logistics outsourcing" is often equated with contract logistics, third- party logistics (3PL) and logistics-services providers. Reference [10] defined third-party logistics as: "using the services of an external supplier to perform some or all of a firm's logistics function". Reference [11] also defined third-party logistics provider as a company that "provides multiple logistics services for its customers". Most recent definition of thirdparty logistics came from reference [12]. Reference [13] defined logistics outsourcing relationships even more broadly as "long and short term contracts or alliances between manufacturing and service firms and third party logistics providers".

After studying previous third-party literature, [12] defined third-party logistics as: "a relationship between a shipper and third-party which, compared with basic services has more customized offerings, encompasses a broader number of service functions and is characterized by a longer-term, more mutually beneficial relationship". Reviewing the definitions pointing at this concept allowed us to define logistics outsourcing as: "the fact of entrusting all or part of the logistic chain, whose activities were previously performed in-house, to an external supplier on the long run, with a potential transfer of resources and with an objective 
of performance" $[14,15]$. This definition, including a strategic dimension, thus, makes outsourcing different from the concepts of subcontracting, contracting out and so on which are often considered close or equivalent to it.

\subsubsection{Partnering}

Reference [16] defined partnerships as "purposive strategic relationships between independent firms who share compatible goals, strive for mutual benefit and acknowledge a high level of interdependence". Reference [17] defined partnering as an on-going relationship between two firms that involves a commitment over an extended time period with a mutual sharing of information, risks, and rewards from the relationship. Reference [18] defined a partnership as "a tailored business relationship based on mutual trust, openness, shared risk and shared rewards that result in business performance greater than would be achieved by the two firms working together in the absence of partnership". The key point in this definition is that the relationship is customized and cannot be uniform for all customers, since the tailoring process consumes managerial time and effort. From the definitions above, it can be noted that partnership agreements are unique and possess elements of relational exchange. Reference [19] pointed out that, although the definitions differ in the literature, partnerships usually share the common characteristics of: long term commitment, open communications and information sharing, cooperative, continuous improvements in cost reductions and increased quality, sharing of risks and rewards. Reference [20] defined a logistics partnership as "a relationship between two entities in the logistics channel that entails a sharing of benefits and burdens over some agreed upon time horizon". Several other definitions include further key characteristics such as information sharing, shared risks and rewards, long-term focus, joint activities and the concept of trust $[21,22,23]$.

\subsubsection{Relationship Marketing}

A comprehensive definition of relationship marketing is provided by [4]: "Relationship marketing refers to all marketing activities directed towards establishing, developing, and maintaining successful relationship exchanges". Although many other definitions of relationship marketing exist in the literature, recent articles have often followed [24] who identified as many as seven conceptual categories and 26 definitions of relationship marketing, arrived at the following definition: "An organization engaged in proactively creating, developing and maintaining committed, interactive and profitable exchanges with selected customers [partners] over time is engaged in relationship marketing" [24]. Note that the word "partners" indicate that the objectives of relationship marketing are to build, maintain, and when necessary, terminate relationships not only with customers, but with stakeholders as well; i.e., suppliers, partners, and even competitors [25]. Reference [4] explained that in order to fully understand the nature of relationship marketing, the first step is to distinguish between a transactional exchange and a relational exchange. A dis- crete transaction involves a single, short time exchange, and has a sharp beginning and ending. A relational exchange, however, encompasses multiple exchanges and usually involves both economic and social bonds [25]. To illustrate the broad range of possible forms of relationship marketing, [4] present ten examples: the partnering involved in relational exchanges between manufacturers and their goods suppliers, as in JIT procurement; relational exchanges with service providers; strategic alliances between firms and their "competitors"; co-marketing alliances and global strategic alliances; alliances with non-profit organizations; partnerships for joint development; longterm exchanges with ultimate customers; relational exchanges with working partners, as in channels of distribution; exchanges involving functional departments; exchanges between a firm and its employees; within firm exchanges such as among subsidiaries or business units. The central idea underlying the relationship marketing concept is, therefore, to build and nurture lasting and mutually beneficial relationships [26]. The expected benefit of systematically developing cooperative and collaborative partnerships is the decrease in exchange uncertainty through customer collaboration and commitment [27]. This notion was born from the fact that organizations have realized that in today's competitive environment, firms need to collaborate in order to compete [28]. Interdependence and cooperation become, therefore, efficient tools to create value and achieve sustainable competitive advantage [29].

\subsection{Theorical Framework}

\subsubsection{Transaction Cost Theory (TTC)}

Pioneered by reference [30] and developed principally by references $[31,32]$, this theory explains the existence of different firms and analyses the optimality of specific coordination mechanisms depending on transaction characteristics. This allows insights into the question why specific activities are carried out internally or are bought from the market [31, 32]. According to [33], "a transaction occurs when a good or service is transferred across a technologically separable interface". The approach as put forward by [30] recognized that there are costs to using the market mechanism. These include the costs of discovering the appropriate price, the cost for negotiating contracts for each exchange transaction and the costs incurred for specifying the details of a transaction in contracts which later were termed "transaction costs" [34]. Transaction costs can be differentiated into ex-ante (before contracts are closed) and ex-post (after contracts are closed) transaction costs [35]. According to [32], transactions can be characterized by the three critical dimensions frequency, uncertainty and asset specificity. According to [36], the most important factor influencing the level of transaction costs is the asset specificity. He defined: "asset specificity has reference to the degree to which an asset can be redeployed to alternative uses and by alternative users without sacrifice of productive value". Applying transaction cost theory, higher asset specificity favors the hierarchy decision. The amount of the 
transaction costs may be used as an indicator for the decision of outsourcing. When asset specificity and uncertainty are low, and transactions are relatively frequent, transactions will be governed by markets-outsourcing. High asset specificity and uncertainty lead to transactional difficulties with transactions held internally within the firm-vertical integration. Transaction cost theory rests on two basic behavioral assumptions about the transaction partners involved: bounded rationality and opportunism. By hypothesizing that firms seek to minimize costs, the theory of transaction cost analysis attempts to predict which activities are internalized and which are transacted via market exchanges. Long-term relationship between firms, based on trust and mutual cooperation, which are replacing the traditional adversarial relationships can improve manufacturing firm performance [37]. The trust between the two parties can play a central role in this context. As [38] pointed out, the generation of trust in a network is suited to lower transaction costs arising e.g. from opportunism. This is due to the fact that an atmosphere of trust is beneficial for more efficient problem solving [39, 40], since information is exchanged freely and more solutions to a problem are being explored because decision makers do not feel the obligation to protect themselves against the others' opportunistic behavior [38]. As these examples for trust and opportunism show, transaction cost theory allows evaluating whether certain variables are beneficial for the governance of logistics relationships. However, as a single theory it is not sufficient to derive the most important variables necessary for adequate relationship governance and therefore needs the input from further theories which will be presented in the following section.

\subsubsection{Social Exchange Theory}

Initially, the transaction cost theory offered an acceptable explanation of governance mechanisms in interorganizational relationships [37]. However, as institutional markets and exchange practices advance, transaction cost theory seems to be losing some of its explanatory power and concepts such as trust and cooperation are gaining increasing importance for understanding successful buyersupplier relationships [41]. To overcome these deficiencies and to find new ways to explain relational exchange, researchers of inter-organizational relationships have recently drawn increasingly on social exchange theory [42]. The concept of social exchange has been suggested by a number of authors to be an important element of successful logistics relationships $[43,44,45,46]$. Social exchange theory allows a deeper insight into how these relationships should be designed in order to enhance their outcomes. This governance mechanism is built on the foundation of trust, commitment, and exchange norms that replace or complement more formal governance mechanisms, such as detailed contracts. In SET, the relationship is the unit of analysis and the key to relational exchange success. Reference [47], for example, explains that relationship development is experienced as a series of exchange episodes. Each ex- change episode is composed of four events: defining the purpose of a relationship, setting relationship boundaries, creating relationship value, and evaluating exchange outcomes. Reference [21] stress the evolution of exchange relationships and propose that relationships develop through five phases, including awareness, exploration, expansion, commitment, and dissolution. According to SET, firms engage in and maintain relationships because they expect that doing so will be rewarding [48]. Therefore, parties will remain in a relationship as long as the parties judge the relationship satisfactory. From a SET perspective, in order to assess whether rewards (i.e., benefits minus costs) are satisfactory, social and economic outcomes are compared to two standards that may vary from party to party [49]: the benefit standard one feels is deserved in a given kind of relationship - the comparison level CL; and the overall benefit that one believes can be obtained from the best possible alternative exchange relationship - the comparison level of alternatives CLalt. The basic foundational premises of social exchange theory according to [42] can be reduced to four points:-Exchange interactions result in economic and/or social outcomes.-These outcomes are compared over time to other exchange alternatives to determine dependence on the exchange relationship. -Positive outcomes over time increase firms' trust on their trading partner(s) and their commitment to the exchange relationship.-Positive exchange interactions over time produce relational exchange norms that govern the exchange relationship.

\subsubsection{Commitment Trust-Theory}

The commitment-trust theory has its roots in the work of [4]. It is a rather young theory which, based on social exchange theory, views commitment and trust as central elements of exchange relationships while at the same time integrating opportunism into the theory whose implicit exclusion had been a major point of criticism for social exchange theory. Origin of the thoughts of [4] was the observation that marketing must distinguish between discrete transactions and relational exchange, which in the time of arm's length relationships commonly was neglected $[21,4,37]$. As relational exchange is becoming more important, relationship marketing is required to adequately address partnership issues. Reference [4] defined: "Relationship marketing refers to all marketing activities directed toward establishing, developing, and maintaining successful relational exchanges". Since the commitment-trust theory therefore enables a deeper insight into the formation of successful exchange relationships even beyond the pure marketing considerations, it presumably is useful for the understanding of logistics relationships.

\section{Conceptual Model and Hypothesis}

\subsection{Antecedents of Trust}

The antecedents of a customer's trust in a 3PL are related to the 3PL behavior towards the relationship: reputation, 
experience of the customer with the 3PL, satisfaction with previous outcomes with the relationship, 3PL's specific investments in a relationship and communication. Fig.1, below, depicts the antecedents of both dimensions of trust (i.e. credibility and benevolence).

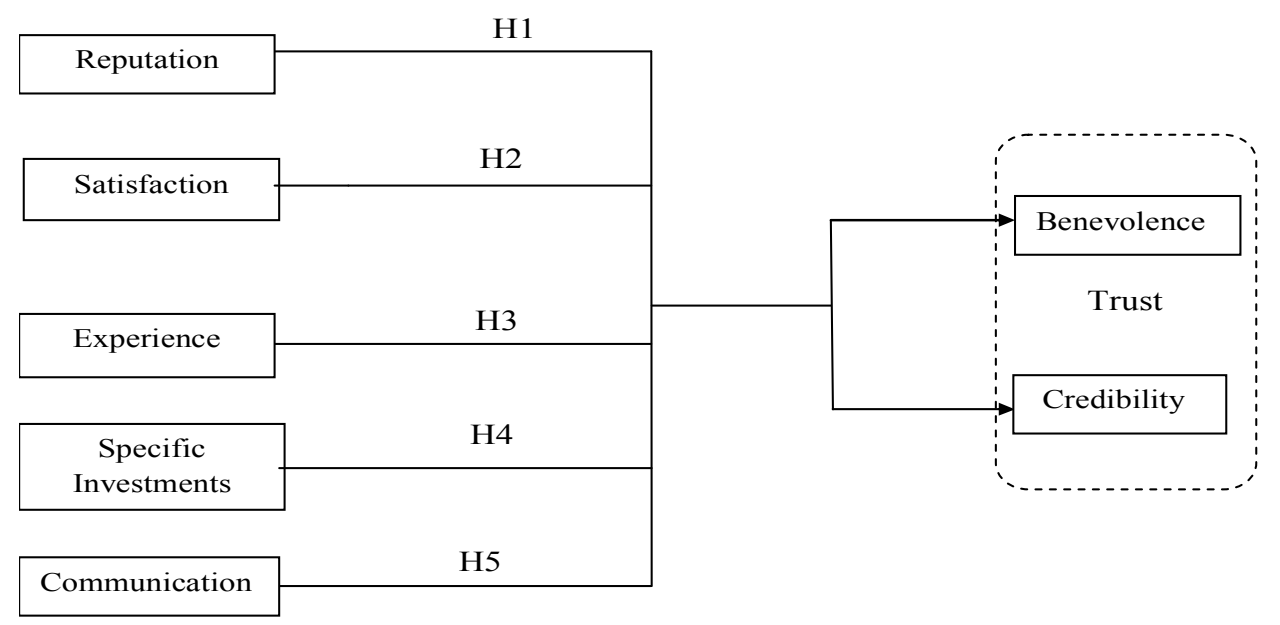

Figure 1. Sub-model of the antecedents of trust

\subsubsection{Reputation and Trust}

Firm reputation is defined as the opinion or perception that stakeholders have about a firm's knowledge, honesty, and care [50,51]. Reputation is one of the most powerful factors in acquiring and retaining customers [52] and has been referred to as a means to achieve competitive advantage [53]. The reputation of a firm is built over time through the demonstration of consistent and reliable behavior [54]. Therefore, if a firm enjoys a credible reputation in a market, it can be inferred that the firm is trustworthy in relationships. Reference [55], for example, in a survey of members of four organizations, found a positive relationship between a partner's reputation in the market and the level of trust in the partner.

H1: The reputation of a $3 \mathrm{PL}$ is positively related to its customer's perception of the 3PL's credibility.

\subsubsection{Satisfaction with Previous Outcomes and Trust}

One of the foundational premises of social exchange theory is that over time, positive outcomes increase trust [42]. As [56] pointed out, social exchange theory postulates that outcomes affect behaviors in subsequent periods. Reference [54] proposed that satisfaction with outcomes positively impact the perception of a partner's credibility and benevolence. This leads to the following hypothesis:

$\mathrm{H} 2$ : A customer's satisfaction with past outcomes is positively related to the customer's perception of the 3PL's trust.

\subsubsection{Experience with $3 P L$ and Trust}

Outsourcing logistics activities enables firms to achieve operational flexibility and efficiency but, on the other hand, requires firms to develop capabilities in order to coordinate their relationship with the 3PL. Relationship marketing scholars, such [21], argue that as experience with a vendor increases, a vendor-customer dyad is more likely to have passed through critical shakeout periods in the relationship.
Reference [57], in a study of co-marketing alliances, argued that a long and stable history of business relations between partners builds trust and commitment, achieving greater effectiveness of the relationship. Reference [58] found a positive association between the historical length of an alliance and the expected continuity of future interaction. Therefore, it is proposed that experience in a relationship with a 3PL provider will positively impact the customer's perception of the 3PL's credibility and benevolence. Specifically:

H3: A customer's experience with a 3PL is positively related to the customer's perception of the 3PL's trust.

\subsubsection{Specific Investments and Trust}

An investment specific to a relationship is tangible evidence that a party is committed to the relationship, and that it cares for such relationship [59]. Indeed, these resources directed specifically towards the other party are the most frequent demonstration of commitment to the relationship [60]. Therefore, it is hypothesized that:

H4: A customer's perception of 3PL specific investments is positively related to the customer's perception of the 3PL's trust.

\subsubsection{Communication and Trust}

Information exchange and communication are key constructs in many empirical studies on interorganizational exchange relationships $[61,4,17,5,62]$. Communication in this study therefore is understood as the formal as well as informal sharing of meaningful and timely information between firms which is suited to achieve the benefits which are desired outcomes of the relationship. Therefore, the following hypothesis will be formulated:

H5: A customer's communication is positively related to the customer's perception of the 3PL's trust.

\subsection{Trust and Commitment}


A number of studies have found a positive relationship between trust and commitment [55, 4]. Trust is a major determinant of relationship commitment [4]. Reference [54] suggested that trust lessens potential risk and vulnerability within the relationship, thus leading to a greater long-term orientation. Furthermore, trust reduces transaction costs since there is not such a need to set up control mechanisms within the relationship [63]. As a consequence of this, these lower costs make it more likely that the relationship will continue in the future and that, therefore, the commitment to the relationship will become greater. Reference [64] indicated that the level of commitment is strongly related to the level of trust. Therefore, we arrive at the following:

H6: There is a positive relationship between the level of trust and the level of commitment. Fig.2, below, depicts the relation between trust and commitment.

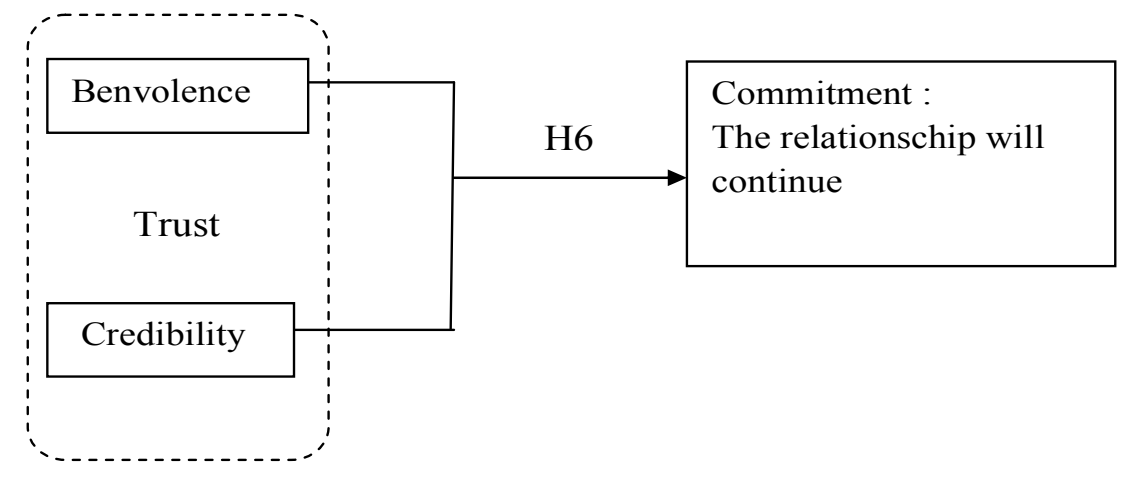

Figure 2. Sub-model of the relation between trust and commitment.

\subsection{Moderating Variable}

Along these lines, time may have a moderating effect on the relationship success. In our study, we consider the duration of the relationship of the service provider with the customer as a moderating variable which can influence the various relations linking trust to its antecedents and to its main consequence: the commitment. This choice is justified with regard to several searches which consider the trust as a dynamic process evolving and strengthening according to the relational phases (fig 3). Therefore, we arrive at the following:

$\mathrm{H}$ 7: the strength of the relations between the antecedents of trust and commitment is affected by the duration of the relation.

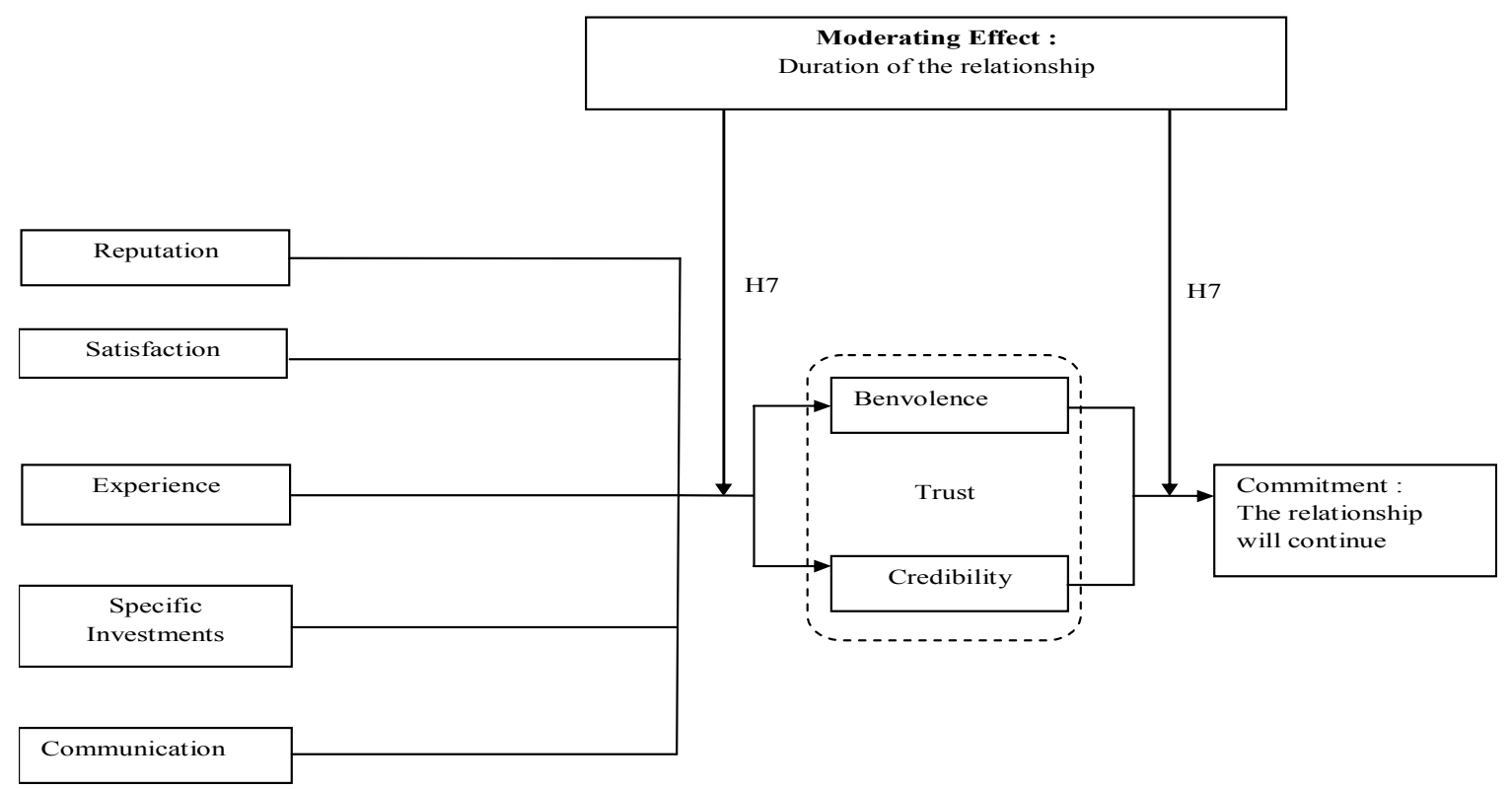

Figure 3. Sub-model of the moderating variable

\subsection{Conceptual Model}

In sum, the present model hypothesizes that the following antecedents of trust will influence a customer's com- mitment with its 3PL: reputation, satisfaction, experience, specific investments and communication. Fig.4, below, depicts the conceptual model. 


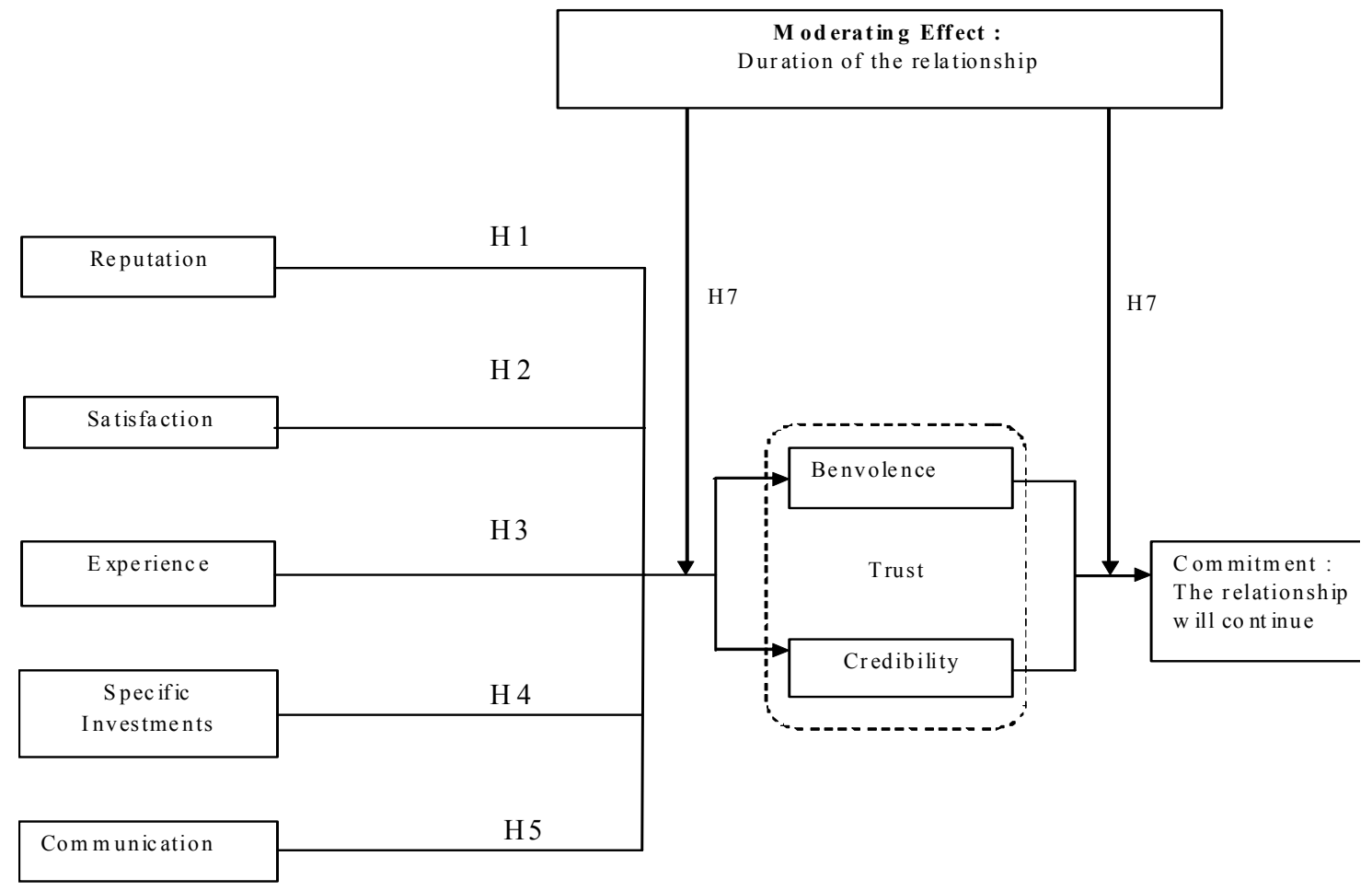

Figure 4. Conceptual model.

\section{Conclusion}

The research study and model development presented in this article represent an additional step forward in our understanding of logistics outsourcing relationship. Although the logistics literature has reinforced the importance of relationship building between 3PLs and their customers, a theoretical and testable model that identifies the factors that lead customers to exhibit partnering behavior is still lacking. The major goal of this study is to investigate the role of trust on the behavioral intentions. To achieve the study's objectives, a number of hypotheses were developed. This paper is not free of limitations. Our research framework and our empirical study will be outlined in our doctoral thesis. We will test and validate the model empirically in the Tunisian building companies.

\section{Acknowledgements}

The authors acknowledge the contribution of the anonymous reviewers whose constructive comments helped to improve the quality of this manuscript.

\section{References}

[1] M. Maloni, C. Carter, "Opportunities for research in thirdparty logistics“, vol.45, $\mathrm{n}^{\circ} 2$, Transportation Journal, 2006, pp.23-38.
[2] R. Lieb, "The use of third-party logistics services by large American manufacturers", vol.13, n ${ }^{\circ}$, Journal of Business Logistics, 1992, pp.29-42.

[3] J-C. Anderson, J-A. Narus, "A model of distributor firm and manufacturer firm working partnerships", vol.54, n 1 , Journal of Marketing, 1990, pp.42-58.

[4] R-M.Morgan, S-D.Hunt,"The commitment-trust theory of relationship marketing", vol.58, $\mathrm{n}^{\circ} 2$, Journal of Marketing, 1994, pp.20-38.

[5] K-R. Moore, "Trust and Relationship Commitment in Logistics Alliances: a Buyer Perspective", vol.34, $n^{\circ} 1$, International Journal of Purchasing and Materials Management, 1998, pp.24-37.

[6] T-P. Stank, T- J. Goldsby, S-K. Vickery, K. Savitskie,” Logistics service performance: Estimating its influence on market share", vol.24, $\mathrm{n}^{\circ} 1$, in: Journal of Business Logistics, 2003, pp. 27-55.

[7] A-M. Knemeyer, P-R. Murphy, "Evaluating the Performance of Third-Party Logistics Arrangements: A Relationship Marketing Perspective",vol.40, $\mathrm{n}^{\circ} 1$, in: The Journal of Supply Chain Management, 2004,pp.35-51.

[8] D-M. Lambert, M-A. Emmelhainz, J-T. Gardner, "Building Successful Logistics Partnerships", vol.20, $\mathrm{n}^{\circ} 1$, in: Journal of Business Logistics, 1999, pp. 165-181.

[9] Y. Bolumole, R.Frankel, D.Naslund, "Developing a theoretical framework for logistics outsourcing, vol.46, $\mathrm{n}^{\circ} 2$. Transportation Journal, 2007, pp. 35-54.

[10] H. Sink, C. J. Langley Jr, "A managerial framework for the acquisition of third-party logistics services", vol.18, n², Journal of Business Logistics, 1997, pp 163- 189. 
[11] R-C. Lieb, H-L. Randall, "1997 CEO perspectives on the current and future projects of the third party logistics industry in the United States", vol.38, n³, Transportation Journal, 1997.

[12] P. Murphy, R. Poist, "Third Party Logistics Some user versus provider perspectives", vol. $21, \mathrm{n}^{\circ} 1$, Journal of Business Logistics, 2000.

[13] E.Rabinovich, R.Windle, M.Dresner, T.Corsi , "Outsourcing of Integrated Logistics Functions: an Examination of Industry Practices", vol.29, n6, International Journal of Physical Distribution \& Logistics Management, 1999, pp.353-373.

[14] P. Murphy, R. Poist, "Third Party Logistics Usage: an assessment of Propositions based on previous research", vol. 37, ${ }^{\circ} 4$, Transportation Journal, 1998, pp.26-35.

[15] S-L. Tage, "Third party logistics - from an interorganizational point of view", vol.30, $\mathrm{n}^{\circ} 2$, International Journal of Physical Distribution and Logistics Management, Bradford, 2000, pp.112-127.

[16] J.Mohr, Spekman R, "Characteristics of Partnership Success: Partnership Attributes, Communication Behavior, and Conflict Resolution Techniques “, vol.15, n², Strategic Management Journal, 1994, pp.135-152.

[17] L-M. Ellram, T-E. Hendrick, "Partnering Characteristics: a Dyadic Perspective", vol.16, ${ }^{\circ} 1$, Journal of Business Logistics, 1995, pp.41-64.

[18] D-M. Lambert , A-M. Knemeyer , J-T.Gardner , "Supply Chain Partnerships: Model Validation and Implementation", vol.25, n², Journal of Business Logistics, 2004, pp.21-42.

[19] J-J. Gentry, "The Role of Carriers in Buyer-Supplier Strategic Partnerships: a Supply Chain Management Approach", vol.17, $\mathrm{n}^{\circ} 2$, Journal of business Logistics, 1996, pp.35-55.

[20] B-J. LaLonde, M-C. Cooper, "Partnerships in Providing Customer Service: A Third-Party Perspective. Oak Brook, IL,1989.

[21] F. Dwyer, PH-S. Robert, Oh. Sejo, "Developing buyer-seller relationships", vol.51, n², Journal of Marketing,1987, pp.11-27.

[22] J.Gattorna, "Building Relationships in Distribution Channels, vol. 21, ${ }^{\circ} 8$, in: International Journal of Physical Distribution \& Logistics Management, 1991, pp.36-39.

[23] L-M. Ellram, T-E. Hendrick, "Partnering Characteristics: a Dyadic Perspective", vol.16, ${ }^{\circ} 1$, Journal of Business Logistics, 1995, pp.41-64.

[24] M-J. Harker, « Relationship Marketing Defined? An Examination of Current Relationship Marketing Definitions », vol. 17, ${ }^{\circ} 1$, Marketing Intelligence and Planning, 1999, pp. 1320.

[25] S. Rao, P. Chad, "Thinking about relationship marketing: where are we now? » vol.17, $n^{\circ} 7$, The Journal of Business \& Industrial Marketing, 2002, pp.598-614.

[26] K. Hewett, B. William O, "Dependence, trust, and relational behavior on the part of foreign subsidiary marketing operations: implications for managing global marketing operations", Journal of Marketing, vol.65, 2001, pp.51-66.

[27] P-H. Andersen, "A Foot in the Door: Relationship Marketing Efforts Towards Transaction-Oriented Customers", vol.5, n², Journal of Market - Focused Management, 2002, p.91.

[28] H-V. Perlmutter, H. David A, "Cooperate to compete globally", Harvard Business Review, 1986, pp.136-152.

[29] T-W. Gruen, "Relationship Marketing: the Route to Marketing Efficiency and Effectiveness ", vol. 40, n 6 , Business Horizons, 1997, pp. 32-38.

[30] R.H. Coase, "The nature of the firm", vol $/ \mathrm{n}^{\circ} \mathrm{NS} 4$, Economica, 1937, pp. 386-405.

[31] O-E. Williamson, "Markets and Hierarchies: Analysis and antitrust implications", The Free Press, New York, 1975.

[32] O-E. Williamson, "The economic institutions of capitalism: Firm, Markets and Relational Contracting", The Free Press, New York, 1985.

[33] O-E.Williamson, "The economics of organization: the transaction cost approach", vol.87, n`56, American Journal of Sociology, 1981, pp.548-577.

[34] K-J.Arrow, "The Organization of Economic Activity: Issues Pertinent to the Choice of Market versus Nonmarket Allocation", in: R. H. Haveman and J. Margolis: Public Expenditure and Policy Analysis, 2. Edition. Chicago, 1970, pp. 6781.

[35] O.E. Williamson, "Transaction-cost economics: the governance of contractual relations", vol.22, $\mathrm{n}^{\circ} 2$, Journal of Law and Economics, 1979, pp.233-259.

[36] O-E.Williamson, "Transaction Cost Economics", in: R. Schmalensee and R. D. Willig: Handbook of Industrial Organization. Amsterdam, New York, Oxford, Tokyo, 1990, pp. 135-182.

[37] J. Hoyt, F. Huq, "From arms-length to collaborative relationships in the supply chain - An evolutionary process", vol 30, $n^{\circ}$, in: International Journal of Physical Distribution \& Logistics Management”, 2000, pp. 750-764.

[38] J-C. Jarillo, "On strategic networks", vol.9, $n^{\circ} 1$, in: Strategic Management Journal, 1988, pp. 31-41.

[39] D-E. Zand, "Trust and Managerial Problem Solving", vol.17, $\mathrm{n}^{\circ} 2$, in: Administrative Science Quarterly, 1972, pp. 229239 .

[40] R-W.Boss, "Trust and Managerial Problem Solving Revisited”, vol.3, n³, in: Group \& Organization Studies, 1978, pp. 331-342.

[41] S. Ghoshal, S. P. Moran, "Bad for practice: A critique of the transaction cost theory" vol.21, $\mathrm{n}^{\circ} 1$, in: Academy of Management Review, 1996, pp. 13-47.

[42] C-J. Lambe, C-M. Wittmann, R-E. Spekmann, "Social Exchange Theory in Research on Business-to-Business Relational Exchange", vol.8, $\mathrm{n}^{\circ} 3$, in: Journal of Business-toBusiness Marketing, 2001,pp. 1-36.

[43] D-J. Bowersox, P-J. Daugherty, C-R. Droge, D-S. Rogers, D-L. Wardlow, "Leading Edge Logistics: Competitive Logistics for the 1990's", Oak Brook, IL, 1989.

[44] B-J. LaLonde, M-C. Cooper, "Partnerships in Providing Customer Service: A Third-Party Perspective. Oak Brook, IL,1989.

[45] K-R. Moore, W-A. Cunningham III, "Social exchange beha- 
vior in logistics relationships: A shipper perspective", vol.29, $\mathrm{n}^{\circ} 2$, in: International Journal of Physical Distribution \& Logistics Management, 1999, pp. 103-121.

[46] J.Weber, C-M. Wallenburg, "Zusatzbeauftragung von Logistikdienstleistern- Empirische Ergebnisse und konzeptionelle Überlegungen zu entsprechenden Defiziten, vol.6, $\mathrm{n}^{\circ} 4$, in: Logistik Management, 2004, pp. 34-46.

[47] J-C.Anderson, "Relationships in Business Markets: Exchange Episodes, Value Creation, and Their Empirical Assessment", 23 Journal of the Academy of Marketing Science 4 (Fall), 1995, pp. 346-50.

[48] P-M. Blau, "Exchange and Power in Social Life. New York: John Wiley \& Sons, 1964.

[49] J-W. Thibaut, H-H. Kelley, "The social psychology of groups”, New York: John Wiley \& Sons, Inc, 1959.

[50] P-M. Doney, J-P. Cannon, "An Examination of the Nature of Trust in Buyer Seller Relationships", vol.61, n², Journal of Marketing, 1997, pp. 35-51.

[51] D-L. Deephouse, "Media reputation as a strategic resource: an integration of mass communication and resource-based theories", vol.26, $\mathrm{n}^{\circ} 6$, Journal of Management, 2000, pp.1091-1112.

[52] P. Jonsson, M. Zineldin, "Achieving high satisfaction in supplier dealer working relationships", vol.8, $n^{\circ} 3 / 4$, Supply Chain Management, 2003, p.224.

[53] J-B. Barney, "Firm resources and sustained competitive advantage", vol.17, $\mathrm{n}^{\circ} 1$, Journal of Management, 1991, pp. 99-120.

[54] S. Ganesan, "Determinants of Long Term Orientation in Buyer-Seller Relationship", vol.58, n², Journal of Marketing, 1994, pp.1-19.

[55] Ik-Whan-G.Kwon, S.Taewon, "Factors Affecting the Level of Trust and Commitment in Supply Chain Relationships", vol.40, ${ }^{\circ} 2$, Journal of Supply Chain Management,2004, p.4.

[56] A-M. Knemeyer, "Logistics outsourcing relationships: an examination of interorganizational trust over the life of the relationship"? PhD, University of Maryland, 2000.

[57] L-P.Bucklin, S. Sanjit, "Organizing successful co-marketing alliances", vol.57, n², Journal of Marketing, 1993, pp.3246.

[58] J-B. Heide, G. John, "Alliance in Industrial Purchasing: the Determinants of Joint Action in Buyer-Supplier Relationship", vol. 27, $\mathrm{n}^{\circ}$ 1, Journal of Marketing Research, 1990, pp. 24-36.

[59] E. Anderson, BA. Weitz, "The use of pledges to build and sustain commitment in distribution channels", vol.29,J. Mark. Res, 1992,pp.18-34.

[60] L-M. Rinehart, J-A. Eckert, R-B. Handfield, T-J. Page Jr, T. Atkin, "An Assessment of Supplier-Customer Relationships", vol.25, n 1 , Journal of Business Logistics, 2004, and pp.25-62.

[61] J-C. Anderson, J-A. Narus, "A model of the distributor's perspective of distributor -manufacturer working relationships", vol. 48, n, Journal of Marketing, 1984, pp. 62-74.

[62] A-M. Knemeyer, T-M. Corsi, P-R. Murphy, "Logistics Outsourcing Relationships: Customer Perspectives", vol.24, $\mathrm{n}^{\circ} 1$, Journal of Business Logistics, 2003.

[63] S. JAP, S. Ganesan, "Control mechanism and the relationship lifecycle: implications for safeguarding specific investments and developing commitment", vol.37, ${ }^{\circ} 2$, Journal of Marketing Research, 2000, pp. 227-245

[64] S-Y. Chu, W-C. Fang, “, Exploring the relationships of trust and commitment in supply chain management", vol.9, $\mathrm{n}^{\circ} 1$, The Journal of American Academy of Business, 2006, pp. 224-228. 